\title{
2: 240058897-239706636
}

National Cancer Institute

\section{Source}

National Cancer Institute. 2:240058897-239706636. NCI Thesaurus. Code C42459.

Physical location of HDAC4_Gene 